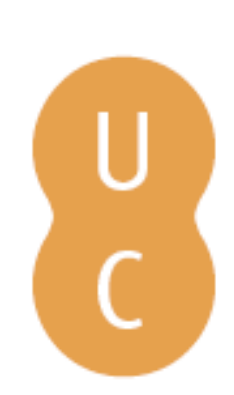

\title{
nombalina
}

Mitologias, Teologias e Taxonomias da História seguindo a ideia bíblica de império

Autor(es): $\quad$ Ramos, José Augusto

Publicado por: Imprensa da Universidade de Coimbra

URL

persistente: URI:http://hdl.handle.net/10316.2/45210

DOI: $\quad$ DOI:https://doi.org/10.14195/978-989-26-1626-1_1

Accessed : $\quad$ 26-Apr-2023 15:33:08

A navegação consulta e descarregamento dos títulos inseridos nas Bibliotecas Digitais UC Digitalis, UC Pombalina e UC Impactum, pressupõem a aceitação plena e sem reservas dos Termos e Condições de Uso destas Bibliotecas Digitais, disponíveis em https://digitalis.uc.pt/pt-pt/termos.

Conforme exposto nos referidos Termos e Condições de Uso, o descarregamento de títulos de acesso restrito requer uma licença válida de autorização devendo o utilizador aceder ao(s) documento(s) a partir de um endereço de IP da instituição detentora da supramencionada licença.

Ao utilizador é apenas permitido o descarregamento para uso pessoal, pelo que o emprego do(s) título(s) descarregado(s) para outro fim, designadamente comercial, carece de autorização do respetivo autor ou editor da obra.

Na medida em que todas as obras da UC Digitalis se encontram protegidas pelo Código do Direito de Autor e Direitos Conexos e demais legislação aplicável, toda a cópia, parcial ou total, deste documento, nos casos em que é legalmente admitida, deverá conter ou fazer-se acompanhar por este aviso.

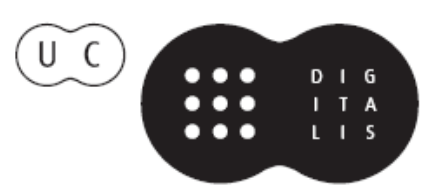




\section{Arqueologias de Império}

\section{Delfim Leão, José Augusto Ramos, Nuno Simões Rodrigues (coords.)}

IMPRENSA DA UNIVERSIDADE DE COIMBRA 


\title{
Mitologias, Teologias e Taxonomias da História SEGUINDO A IDEIA BÍBLICA DE IMPÉRIO' \\ (Mythologies, Theologies and Taxonomies of History through the biblical idea of empire)
}

\author{
José Augusto Ramos \\ (joseramos@letras.ulisboa.pt; ORCID: 0000-0002-3247-2163) \\ Universidade de Lisboa, Centro de História
}

\begin{abstract}
Resumo - Apesar de o discurso político das culturas orientais não ter elaborado especificamente o conceito de império, a historiografia assume que se podem exprimir com ele os dinamismos de várias das suas épocas. Na Bíblia, o conceito de império informa a sua concepção do tempo, representando a realidade das múltiplas subserviências históricas bem como as suas configurações míticas e teológicas.

Palavras-Chave: Egipto. Assíria, Babilónia, Selêucidas, Romanos, Quinto Império

AвSTRACT - Although the political speech of the Eastern cultures did not specifically elaborate the concept of empire, historiography assumes that the dynamism of several of its epochs can be expressed with it. In the Bible, the concept of Empire informs its conception of time, representing the reality of the multiple historical dominations as well as its mythic and theological configurations.
\end{abstract}

Keywords: Egypt. Assyria, Babylon, Seleucids, Romans, Fifth Empire

Os textos recolhidos nesta edição reportam-se a um horizonte de História Antiga em que o principal elemento ordenador da longa duração histórica é a ideia de império. As abordagens apresentadas tratam a questão em diversas épocas e em múltiplas situações diversificadas. Entretanto, é realmente no vocabulário político enraizado na época do Império Romano que esta designação verdadeiramente se origina, apesar de a ideia de império ser significativa e muito frequentemente utilizada na historiografia para representar um ordenamento político e formular sínteses históricas a respeito de épocas muito remotas. E se é de Roma que lhe vem o nome de império, daí virá também boa parte da definição mais explícita do conceito.

Neste contexto romano, com efeito, as linhas de força da semântica de império definem-se a partir de um contexto militar, onde uma figura de sucesso aparece rotulada de imperator e vai sendo sucessivamente projectada para uma função política de poder e soberania, encontrando-se à cabeça de todo um

\footnotetext{
${ }^{1}$ Este trabalho é financiado por Fundos Nacionais através da FCT - Fundação para a Ciência e a Tecnologia no âmbito do projecto UID/HIS/04311/2013.
} 
universo geográfico e populacional que o imenso exército romano podia realmente representar. Um tal sucesso e representatividade na vertente militar, acrescido de um poder alargado, intenso e dominador são conotações características que se acentuam na ideia de império, no momento em que este conceito passa a ser transferido para outra entidade histórica específica. Mesmo não constituindo nomenclatura política explícita dos mundos orientais pré-clássicos, o conceito e imagem dos impérios tem-se mostrado muito naturalmente adequado para representar entidades políticas de especial impacte, sobretudo tratando-se de uma força política externa que domina ou simplesmente condiciona e enquadra a história de povos e nações à sua volta. Neste sentido, o mundo oriental não usou esta designação, mas de imediato sugeriu claramente que esta imagem e conteúdo se lhe podiam aplicar de forma adequada.

Não pode caber aqui a pretensão de esquadrinhar toda a arqueologia oriental dos matizes que confluem para o conceito de império, definindo assim o conteúdo que precede e veio a informar a posterior designação. É, no entanto, inegável que a cultura e a historiografia política do Oriente, desde havia muito tempo, desenvolviam modalidades categoriais precursoras da ideia de império. Em convergência com as análises e prestações que foram recolhidas neste volume temático, apenas pretendemos valorizar o testemunho bíblico sobre a capacidade de sistematização da história bem como das suas fases e realidades, para as quais esta ideia aparece requisitada. Este é provavelmente um dos aspectos em que a Bíblia oferece um horizonte mais pertinente sobre o seu mundo, que abarca a totalidade do mundo pré-clássico.

Nos textos originais da Bíblia fala-se de reis e de reinos em termos concretos ou de realeza em abstracto, mas nas traduções e comentários, em discurso mais historiográfico, recorre-se frequentemente à designação mais ampla de império. Para justificar esta equivalência conceptual, convergem os dados que caracterizariam o termo na semântica romana em que assentou o nome. Isto é, sublinha-se o poderio militar e uma soberania política que tende para uma hegemonia, com traços de comportamento excessivo e, de algum modo, indevido e absoluto. A utilização deste conceito implica, por um lado, uma avaliação do processo histórico visto pelos seus níveis de sucesso e pelas suas dimensões de injustiça. $\mathrm{O}$ discurso bíblico que se reporta a esta imagem toma-a como portadora de injustiça e de opressão. A voz é a dos oprimidos². Todavia, apesar desta negatividade, frequentemente dramática, os momentos nevrálgicos de hegemonia representados por potências dominantes servem de maneira inteiramente lógica para sobre a linha dos impérios assentar a mais eficaz periodização de toda a duração histórica, como marcos no seu longo percurso.

\footnotetext{
${ }^{2}$ A injusta desumanidade deste poder absoluto está na base do confronto entre o poder imperial romano e os primeiros cristãos. Cf. Jones 1992, 5:806-9.
} 
Neste espaço funcionalmente delimitado, apenas se podem sintetizar alguns tópicos da imensa riqueza de matizes que este conceito chave é chamado a exercer na leitura, ordenamento e representação da história humana que se espelha no horizonte da Bíblia.

\section{IMPÉRIOS DE HORIZONTE MÍTICO}

As mais marcantes figuras da História tendem naturalmente para garantir assento na galeria de formas míticas da literatura essencial. Dentro da Bíblia, esta literatura mítica essencial da História, na mais pertinente acepção que faz dela um universal humano, encontra-se distendida ao longo dos primeiros 11 capítulos do Génesis. E é precisamente ali que nos deparamos com a figura de Nimerod, «o primeiro homem poderoso sobre a terra $»^{3}$.

Com este nome de Nimerod, a concentrar em si diversas toponímias e onomásticas, parece ter sido sintetizada e personificada a memória de virtualidades imperiais que o longo passado da Mesopotâmia foi acumulando, designadamente as da Suméria e Babilónia, conjuntamente designadas com o nome de Chinear, e ainda a Assíria. As conotações de força e habilidade militar, a significativa difusão e ressonância do seu poder, bem como o carácter inaugural e institucionalmente constituinte da sua imagem são, desde muito cedo, características chamadas a integrar o conceito de império. A origem desta personagem, Nimerod, comporta desde logo referências africanas, pois é apresentado como filho de Cam, o segundo filho do mítico patriarca Noé, de quem descenderiam as populações primitivas da região nordeste do continente africano, onde, na antiguidade, pontificou o Egipto faraónico. A sua memória, porém, transcende o mundo egípcio propriamente dito. Mesmo que este desvio exagerado para os lados da África possa ser fruto de uma confusão entre os cuchitas, gentes de África, e os cassitas, gentes da Mesopotâmia, esta amplificação geográfica com a consequente extensão semântica enquadra-se bem, como verdade própria da mítica figura imperial de Nimerod ${ }^{4}$.

O nome e a imagem de Nimerod parecem ter possibilidades de se articular, nas profundidades da semântica histórica, com grandes figuras de poder real como Tukulti Ninurta, do império médio assírio, e bem assim com representantes da mitologia do poder como sejam os próprios deuses mesopotâmicos, Ninurta e Marduk. A confluência natural entre níveis humanos e divinos do poder, segundo a concepção oriental antiga, é uma das características do conceito de império. Por essa razão, muitas memórias da cultura mesopotâmica conservadas pelos hebreus podem confluir para dar conotações à

\footnotetext{
${ }^{3}$ Cf. Gn 10:8; 1Cr 1:10.

${ }^{4}$ Cf. Gn 10:8-12; Speiser 1964, 69-73.
} 
imagem de Nimerod ${ }^{5}$. No livro do profeta Miqueias ${ }^{6}$, contemporâneo da fase ascendente do império neo-assírio, Nimerod é associado precisamente com o império assírio.

No interior de uma saga familiar e regional que dizia respeito ao clã patriarcal de Abraão e Lot, o mesmo bloco mesopotâmico de um poder de intensa ressonância e ampla repercussão aparece representado pela fórmula política de uma pentápole, onde pontificam nomes de reis aos quais o tempo já impusera formas de erosão. Por isso, alguns daqueles nomes escapam à tentativa de identificação com figuras históricas conhecidas. Era precisamente o que acontecia com o nome do próprio Nimerod ${ }^{7}$. O império unificado que aqui parece andar implícito, sob a forma de uma coligação de reis, é o de Amerafel, rei de Chinear; Arioc, rei de Elassar; Cadorlaomer, rei de Elam; Tidal, rei de Goim. A sequência da narrativa ${ }^{8}$ acaba por colocar Cadorlaomer na posição de liderança e apresenta-o como a personificação daquele grande poder que ameaçava o bem-estar da família patriarcal de Abraão. Deste quadro resulta uma imagem ameaçadora e ao mesmo tempo frágil até quase ao ridículo9. Estas são características paradoxais que denotam biblicamente o conceito de império.

Também neste caso como na anterior ocorrência de Nimerod, o concentrado de referências geográficas e de nomes parece convergir bem com o aglomerado mítico perceptível na referência que se projeta para um tempo paradigmático das origens. É assim que acontece no início das grandes narrativas míticas da Mesopotâmia ${ }^{10}$. A ideia de poder está, naquela narrativa, marcada pela significativa aglomeração de reis de grandes potências, enquanto Abraão os enfrentava com as poucas centenas dos seus homens ${ }^{11}$.

Face à grandeza do império aparece a pequenez das forças que lhe oferecem resistência. Neste desfasamento e evidente desequilíbrio de forças consiste a grandeza do milagre! É a mesma fórmula simbólica de desproporção que se verifica na confrontação entre David e Golias ${ }^{12}$. O jogo desequilibrado entre o império e as suas vítimas é sempre um campo de maravilha. Esta capacidade de alimentar a expectativa de um milagre é a força de resistência dos condenados.

${ }^{5}$ Cf. Machinist 1992, 4:1116-118.

${ }^{6} \mathrm{Mq}$ 5:5.

${ }^{7} \mathrm{Gn} 14: 1$.

${ }^{8} \mathrm{Gn} 14: 4-9$.

${ }^{9}$ Abraão com os seus trezentos e dezoito servos a desbaratar a grande coligação de reis com seus exércitos (Gn 14:14-16) comporta uma situação lógica que pode ter atractivos de maravilhoso, mas é, sem dúvida, humorística no seu desequilíbrio.

${ }^{10}$ A formula narrativa do "quando", segundo as modalidades narrativas conhecidas no antigo Oriente, traduz uma específica profundidade mítica e remete para o tempo primordial, tal como acontece no início das grandes narrativas de Atrahhasis e de Enuma elish.

${ }^{11} \mathrm{Gn} 14: 14$.

12 S $17: 1-58$. 
É o que dá resistência ao pensamento apocalíptico, que assenta a sua resistência numa atitude de tipo quietista e confiante ${ }^{13}$.

Estas referências poderiam mesmo ser um concentrado onde se acumulam as imagens dos inimigos de fora, identificados simplesmente como inimigos de Abraão e seus vizinhos, podendo mesmo não serem vizinhos entre si. Com efeito, o último nome daquele grupo de reis coligados, o rei de Goim, nome que quer dizer "povos», poderia mesmo estar ali já como simples referência genérica aos outros povos, tomados como diferentes e eventualmente como inimigos de Israel ${ }^{14}$. Estes inimigos podiam sê-lo realmente ou virtualmente; e podiam até ser inimigos apenas paradigmaticamente. O conceito bíblico de império é o de um poder exterior, condicionador e soberano. Nem precisa forçosamente de ser uma fórmula institucional específica e formal. Por isso a Bíblia considera como impérios certas realidades políticas que, na realidade, nos pode parecer que não justificariam semelhante rótulo. Uma boa parte das referências bíblicas a forças externas de hegemonia e domínio, situadas ao longo da história dos hebreus, podem caber neste modelo de designação abrangente.

\section{IMPÉRIOS DE HORIZONTE HISTÓRICO}

A história bíblica não proporcionou quase nunca ao povo dos hebreus a possibilidade de viverem como numa ilha, em condições de autossuficiência e de isolamento político e cultural. A longa duração que nela aparece espelhada, quer na sua realização concreta quer nos seus percursos de memória, encontra-se explicitamente articulada em referências maiores que lhe servem de enquadramento. É aqui que nos deparamos com as referências aos impérios, numa função natural que consiste em ir proporcionando definições e enquadramentos, por meio dos quais o tempo histórico se vai configurando. O tempo dos hebreus e a sua narrativa histórica são recortados pelas transformações sucessivas de enquadramento em que uma potência estrangeira se situa como referência, seja porque se afirma com hegemonia indirecta, seja porque se constitui segundo a fórmula de um domínio directo. É o figurino dos impérios predominantes, que podem na realidade ser qualitativamente diferentes, em versões boas ou más, mas que produzem sempre efeitos de condicionamento histórico análogos sobre a vida dos povos e sobre a sua identidade.

Nesta perspectiva, a potência política e civilizacional que desde mais cedo e em época histórica serve de referência incontornável para a história dos hebreus é o Egipto, cuja presença continuada se recorta no horizonte da

\footnotetext{
${ }^{13}$ Por muito que ande associada a imagens de combate, a apocalíptica é uma maneira de se confrontar com as injustiças da História de maneira quietista, isto é, fazendo delas um manifesto sonante como declaração de princípios, mas sem se organizar para a guerra.

${ }^{14}$ Cf. Speiser 1964, 105-9; Astour 1992, 2:1057.
} 
época pré-monárquica e se projecta por sobre todo o tempo dos patriarcas. Com períodos de maior ou menor domínio, este é um império que suscita medo e mantém uma ameaça constante de opressão. Por outro lado, e no entanto, o Egipto também oferece expectativas garantidas de esperança e de vida. A sua imagem enquanto referência hegemónica é, por conseguinte, de ressonância ambivalente, como o são, em geral e por sua natureza, todos os impérios. As fases e coloridos com que se apresenta a história sociopolítica do Egipto, nas suas sucessivas repercussões internacionais, todas elas se repercutem de imediato e de forma muito concreta em vicissitudes práticas de todo o género para a história da Bíblia. Apesar dos altos e baixos, mais ou menos notórios e significativos, que vão conhecendo, os 3000 anos de história oferecem maleabilidade suficiente para que o Egipto possa marcar a sua presença de forma continuada. Mesmo quando não lhe cabe o papel principal, mantém-se por perto, como força imperial de segunda referência e de recurso. É, com efeito, sob a égide do Egipto que a história bíblica se inicia. O impacte desta imagem imperial do Egipto paira por cima da literatura essencial dos hebreus, concentrada no Pentateuco.

Desde o século X até à segunda metade do século VII a. C., os hebreus viveram sob a hegemonia internacional e sucessivamente sob o domínio do império assírio. Na sua vizinhança, outras entidades políticas concretas podem não chegar a merecer a designação de império, apesar de mostrarem conteúdos e comportamentos sociais e políticos de grande relevância. Poderíamos considerar aqui o impacte político dos filisteus e dos fenícios. Com efeito, estes apresentavam ressonâncias agressivas de alteridade cultural e política e assumiam motivações específicas de concorrência, mas não eram potências de marcação hegemónica durável nem de amplitude significativa. A sua sombra apreende-se com algum impacte por sobre os livros de Juízes, Samuel e Reis, mas a sua conotação é mais de vizinhos incómodos que de impérios dominantes.

A partir da segunda metade do século VIII, a Assíria, servindo-se de uma fórmula de afirmação política da Mesopotâmia, em época mais recente, afirma-se poderosamente no palco internacional onde as duas monarquias do Israel daquela altura tinham de se movimentar. Alguns aspectos desta dimensão imperial assíria tornaram-se bastante visíveis no reino do Norte, a Samaria, mais que no reino do Sul, o de Judá. A conquista militar e o recurso a uma metodologia radical de erradicação da personalidade política nacional são o modelo mais sofisticado da sua estratégia de domínio como potência imperial ${ }^{15}$. É habitual que a historiografia considere o aparecimento subsequente dos samaritanos como uma transformação de uma política imperial que gerou um facto sociocultural e político perene e persistente, até aos dias de hoje ${ }^{16}$. No

\footnotetext{
${ }^{15}$ Cf 2 Rs 17.

${ }^{16}$ 2Rs $17 ; 6: 24-41$.
} 
horizonte do livro dos Reis, das Crónicas e de Isaías, é marcante o efeito da hegemonia e do domínio exercidos pelos assírios, mesmo sobre o reino do Sul, o de Judá, que, apesar de assédios e cercos, não chegaram a conquistar ${ }^{17}$. Sobre os reinos dos hebreus a sua hegemonia foi curta mas foi profunda em consequências, de molde a transformar-se em memória paradigmática de império opressor que ficou longamente registada na cultura bíblica ${ }^{18}$.

A potência imperial que se seguiu foi o império neobabilónico. Historicamente, a Babilónia tinha já conhecido fases de modelo imperial anteriores no horizonte da Mesopotâmia. Para o horizonte político dos hebreus, no entanto, esta última Babilónia, a de Nabucodonosor, é aquela que verdadeiramente interessa, pois marca profundamente a experiência do reino de Judá e cola-se à memória histórica subsequente dos judeus. A sua política condiciona definitivamente o futuro cultural deste povo, contribuindo decisivamente para a própria configuração das suas memórias e da sua identidade com que se define. As várias imagens da Babilónia de fases anteriores podem ser culturalmente matriciais, mas não são politicamente hegemónicas para os hebreus. Não tinham, por isso, justificado para eles o título de impérios. Esta última fase, porém, apesar de ter sido bastante rápida, foi absolutamente radical e mereceu, por isso, a designação de potência imperial na sua acepção mais intensa. Por isso, algumas das personagens desta época aparecem projectadas para o horizonte das linguagens e coordenadas mais marcantes do discurso bíblico sobre os imperialismos. A sua fisionomia de cidade-império oferece a fórmula e designação metafórica para a cidade-império que aparenta dominar o mundo, tal como se recorta no horizonte do Apocalipse ${ }^{19}$. É nos livros de Jeremias e Ezequiel que podemos encontrar, em registo de cariz contemporâneo e dramático, as várias tonalidades com que se pinta o império neobabilónico ${ }^{20}$. A segunda parte do livro de Isaías espelha o que o império neobabilónico deixou de sofrimento, mas sugere já muito daquilo que ele está a permitir como esperança ${ }^{21}$.

Sem deixar de ter uma específica proeminência simbólica, que conservou durante séculos na cultura bíblica, o império babilónico foi rapidamente substituído pela presença do império persa, que assumiu toda a sua expansão política e territorial. Uma sua primeira fase, transitória, é culturalmente caracterizada como medo-persa, tendo a fase de domínio da Média sido rapidamente ultrapassada. Este império persa ou aqueménida durou por mais de dois séculos e representou uma modalidade mais burocrática, administrativa e civilizacional

\footnotetext{
${ }^{17}$ 2Rs 18:13-37; 2Cr. 32; Is. 36-37.

${ }^{18} \mathrm{O}$ livro de Judite, um romance histórico provavelmente escrito no século II a. C., trata o próprio rei neobabilónico Nabucodonosor como se fosse um imperador da Assíria (Jd. 1.1).

${ }^{19}$ Ap 17:18.

${ }^{20}$ Jr. 34; 37-39; Ez 1-11.

${ }^{21}$ Is. 40 ss.
} 
do que militar. Em matéria de relacionamento político e cultural, a sua mentalidade era mais aberta e colaborante que a dos dois impérios mesopotâmicos anteriores.

Para as gentes do Oriente, o tempo dos Persas mantém um modelo imperial, pouco marcado do ponto de vista militar e não muito exigente do ponto de vista económico. Se excluirmos as relações com o Egipto e com a Grécia, este modo de relacionamento do império persa foi particularmente tranquilo, comparativamente a outras áreas políticas e culturais. Por isso, se justifica o rótulo de uma época de paz dos Aqueménidas. No panorama do Oriente, este caso é um bom contributo para um conceito positivo dos impérios. Este império persa serve de pano de fundo para os livros de Ageu, Zacarias, Esdras, Neemias e enquadra uma fase de grande produtividade literária para a memória bíblica. Durante os séculos que durou para os hebreus o império persa, constituiu o enquadramento para uma longa experiência da comunidade hebraica como uma realidade sobretudo identificada com um modelo cultural, centrada na função do sumo sacerdote de Jerusalém.

$\mathrm{Na}$ época helenística e pela consciência histórica que se apercebe na literatura bíblica, a forma de império que se pode descortinar, em primeiro lugar, é a do helenismo alexandrino. Esta época é de boa convivência entre a cultura grega e a tradicional cultura bíblica; a relação é algo semelhante, em termos de ecumenismo cultural, ao que acontecera no tempo dos persas, apesar de a mentalidade judaica nem sempre lhe retribuir com atitudes de igual simpatia. Foi a era de helenismo otimista para os judeus.

Depois dos primeiros cerca de cem anos mais sossegados e, por isso, com menos história, seguiu-se uma outra fase de helenismo que decorreu sob o domínio político dos selêucidas de Antioquia. Não era muito vistoso, mas foi particularmente incisivo no que diz respeito aos judeus. Muito do que na Bíblia e no judeo-cristianismo foi ganhando forma ficou a dever-se ao período de um século e meio que medeia entre o tempo do helenismo dos selêucidas e a entrada em cena do último império que afecta realmente a historiografia bíblica, isto é o Império Romano. No âmbito helenista, temos grande convergência do património cultural bíblico com o mundo cultural de raiz grega, expressa na tradução da Bíblia para o grego, em Alexandria, e em livros bíblicos como o de Daniel, da Sabedoria, os dois livros dos Macabeus e muitos outros. O confronto com os impérios gregos e romanos induz uma grande produtividade literária entre os hebreus, onde se insere praticamente todo o Novo Testamento.

Lucas, autor dos textos de cariz mais claramente historiográfico para as origens do cristianismo, assume o horizonte do império romano, com naturalidade e algum entusiasmo, como enquadramento histórico para apresentar o 
nascimento de Jesus ${ }^{22}$. Esta referência, de tonalidade aparentemente feliz, parece destinada a evoluir, com alguma satisfação, em direção ao ponto em que o cristianismo passaria a assumir os destinos antropológicos de todo o mundo representado pelo Império Romano. Esta feliz convergência estava de algum modo preparada na assunção de importantes modalidades helenísticas de cultura, que fizeram do modelo de cristianismo que chegou até nós um cristianismo de recepção grega. Por isso o cristianismo parece assumir com naturalidade e consciência o horizonte ecuménico do império romano como representando o âmbito do humano universal. É esta a sensibilidade dos anos setenta do século primeiro da nossa era, que se espraia pela literatura lucana, desde o Evangelho até aos Atos dos Apóstolos. Esta imagem unificada do mundo no horizonte de Roma poderia, mais uma vez, representar a versão positiva da ideia de império e um vislumbre de uma consciência de globalização humanitária.

Pelo contrário, é evidente que o livro do Apocalipse, apenas vinte ou trinta anos depois das perspectivas positivas de Lucas sobre o império romano, está já bastante longe de pintar com as mesmas cores de agrado os sentimentos de desagrado que o império romano provocava junto de muitos cristãos.

\section{IMPÉRIOS EVENTUALMENTE OMISSOS}

Algumas fases da história da Bíblia poderão ter eventualmente ficado menos claras na memória que as várias gerações retiveram e na historiografia que se foi fazendo. Já referimos que a memória histórica da Bíblia é demasiado recente e não teve amplidão suficiente para poder conservar incidências directas de impérios de origem mesopotâmica muito antiga. A Mesopotâmia e as regiões que lhe são afins funcionam para o mundo bíblico muito mais como matriz do que como percurso compartilhado. Os próprios sumérios tiveram momentos históricos de teor imperial. O império acádico tem significativas razões para justificar o papel pioneiro que lhe é reconhecido para a fórmula dos impérios. E até a cidade síria de Ebla, logo a seguir ao tempo de predomínio acádico, se poderia gabar de um certo ascendente regional de características algo imperiais, ainda no decurso do terceiro milénio, antes de Cristo.

A mesma coisa se pode dizer da era histórica de predomínio regional que coube aos hititas, que aconteceu numa época em que estaria ainda muito embrionário o processo de definição étnica e política que conduziu à formação do grupo dos hebreus. Com efeito, estes hebreus conservaram memórias dispersas dos hititas, que eles designam com o nome de heteus. As referências a este povo, são já memórias radicadas no interior da história das tribos hebraicas. E se os hititas ou heteus marcam presença na memória dos hebreus, eles não chegaram,

\footnotetext{
${ }^{22}$ Lc. $2: 1-6$; 3:1-3.
} 
no entanto, a tempo de se apresentar com a definição clara de um império completo, que impõe regras políticas e define e limita condições de vida.

A mesma coisa se deve dizer de núcleos de hegemonia internacional que afectaram, de forma significativa, algumas regiões geograficamente vizinhas da Bíblia, mas que ali não chegaram a implantar marcas notórias de poder imperial. É o caso dos hurritas, que, mais uma vez, aparecem em referências intersticiais desfocadas com o nome de horritas. O seu nome perde-se entre a imensidão de povos referenciados no passado bíblico-cananaico. É evidentemente rápida a história daquilo que não foi, mas a hipótese de existirem épocas de impérios que o exercício da memória histórica deixou omissos é um elemento igualmente importante.

A questão do condicionamento da história bíblica pela acção de entidades políticas externas acaba por coincidir com as relações políticas que se verificam em relação a qualquer entidade estrangeira que, num dado momento ou de forma permanente, tenha interferência no teor de vida da sociedade hebraica. Pode entrar nesta perspectiva, de algum modo, o caso de todos os povos que, ao longo da Bíblia, foram sendo objecto de um pronunciamento ou de juízo histórico expresso sob a forma de oráculos proféticos ${ }^{23}$. Nestes oráculos de condenação política está marcado aquilo que é diferente e que é inimigo. Por isso esses oráculos se apresentam sob a forma de uma ameaça, um juízo negativo e condenatório sobre as actividades políticas desses povos. Estes exemplos podem ser considerados como uma imagem desmultiplicada de todas as conotações negativas com que se caracteriza a ideia de império. Com isto se apresentam personificados todos os casos do outro que, enquanto poder, é visto como um inimigo.

\section{OS IMPÉRIOS DE HORIZONTE APOCALÍPTICO}

O olhar característico que a apocalíptica desenvolveu a respeito da História levou a que, nesse ambiente, o conceito de império se tivesse cristalizado na sua forma mais representativa, em toda a amplitude do horizonte bíblico e mesmo para toda a duração do mundo. Na sua forma cumulativa e evolutiva, a apocalíptica desenvolveu uma visão articulada e integral da História que poderia dar particular significado ao papel desempenhado pelas potências políticas; em torno a elas se organiza e decorre a vida das sociedades ao longo do tempo. Vários textos de sabor apocalíptico, na época de ouro desta produção literária, que foi a partir do século II a. C., cultivaram, assim, uma visão integral da História e deleitaram-se em a expor de forma pormenorizada, de modo a dar

\footnotetext{
${ }^{23}$ É muito frequente nos profetas o aparecimento de oráculos de julgamento relativamente ao comportamento político das nações e cidades estrangeiras para com o povo de Israel. Veja-se, por exemplo, Is. 14-24, 34:46-47; Jr. 25-38, 46-51; Ez. 25-31; Jl. 4; Am. 1-2; Na. 2-3; Sf. 1-2. Cf. Ramos 2013, 34-35..
} 
evidência persuasiva à sua argumentação. Um caso vistoso deste recurso é o do Apocalipse das Semanas, integrado na literatura do ciclo de Henoc ${ }^{24}$. A partir do tempo daquele patriarca antediluviano, a história do mundo futuro apresenta-se dividida em dez semanas. A semana que representa o tempo do autor e da escrita desta narrativa, que deve ter acontecido por volta de 160 a.C., é contada como sendo a oitava e esta é classificada como sendo a do grande sofrimento. O trágico da História está no presente. Seguir-se-á a semana do desfecho e da destruição, vindo toda a marcha da História a culminar na semana eterna de um novo céu e uma nova terra, isto é a reposição da ordem ideal desejada para as sociedades e para o mundo.

Tornou-se, entretanto, clássica na tradição apocalíptica uma formulação destes impérios que se revela essencial para o modo como decorrem os vários períodos da História. O livro de Daniel ${ }^{25}$ fez desta sequência o esquema integral do tempo e instituiu-o de tal modo que este passou a servir de fórmula perene para o pensamento apocalíptico. Mais do que uma sensibilidade mítica demasiado ampla da História, esta literatura concentrava-se numa visão historiográfica e historiométrica de maior proximidade, que incidia directamente sobre o contexto político e afectava a vida dos hebreus ${ }^{26}$. Na época em que isto estava a acontecer, estes hebreus podem claramente ser já designados com o nome de judeus. Os impérios desta história apocalíptica ficaram sintetizados numa sequência intensa, sob a forma de cinco impérios. Com eles se pretendia apresentar um esquema capaz de sintetizar todas as aventuras da história humana, antes da sua chegada à meta ideal, que seria a de uma ordem universal garantida. É o desejo assumido como meta incontornável.

O Império Babilónico, em virtude dos acontecimentos paradigmáticos da destruição de Jerusalém e do exílio, em 587/586, foi e ficará a ser a referência modelar. O Império Médio é contabilizado como o segundo, apesar de a sua incidência directa sobre a história da Judeia ser bastante mais modesta. O terceiro é o Império Persa. O quarto é o império que ocupa o tempo presente da escrita, situado por volta de meados do século II a. C. O quinto império corresponde ao tempo sobre o qual se projecta a antevisão mítica do futuro. Podemos dizer que o primeiro dos cinco impérios representa a definição histórica de império enquanto potência maligna; o segundo e o terceiro são referências de continuidade para exprimir a longa e paciente realidade que é a experiência histórica; o quarto é aquele de que se faz uma narrativa pormenorizada e dramática, uma vez que ali é que se situam os graves problemas humanos, culturais e políticos dignos de condenação que constituem a experiência política e

\footnotetext{
${ }^{24}$ Integrado entre os cc. 91 e 93 do Livro de Henoc. Cf Collins 2010, 101-5. Diez Macho 1984, 15ss.

${ }^{25}$ Cf. Dn. 2:39ss; 7:1, 7:19-25; 8-11.

${ }^{26}$ Collins 2010, 151-63.
} 
cultural da insatisfação. Desta maneira, o império do presente fica sobrecarregado com toda a injustiça e dramatismo que os seus oprimidos experimentam. O quinto representa a radical mudança de horizonte e de tonalidade literária; é o império do futuro, pois comporta toda a utopia e todos os ideais. É a utopia paradisíaca, em coordenadas e modalidades completamente opostas às da História. Este horizonte de utopia vai-se mantendo afastado, por exigências do próprio estatuto da utopia, apesar de a intensidade das expectativas continuar a sugerir sempre grande aproximação e requerer muita urgência. É, de facto, o sentimento de urgência que caracteriza este estado de espírito. A vontade de proceder a uma intensa revisão da História é em si mesma um processo de aceleração e de impaciência.

Porém, como a utopia vai tardando em tornar-se realidade, a solução para os prolongamentos diferenciados consiste em ir procedendo a novas e sucessivas identificações para o quarto império, que domina cada época presente dos sucessivos sujeitos da consciência histórica. É assim que assistimos, ao longo de séculos de História, a sucessivas identificações do quarto império ${ }^{27}$. Este tem sido o espaço onde sucessivos autores, em séculos diferentes, se têm esforçado por fazer uma releitura e apresentar uma reconstrução do processo histórico ao longo dos séculos. Na primeira visão de Daniel, este quarto e terrível império era o dos Gregos de Alexandre Magno, corporizados principalmente pela dinastia dos Selêucidas. Pouco depois, já em plena época do Novo Testamento, o quarto império passou a ser identificado com o império dos romanos. Com o passar longo dos séculos, o próprio cristianismo e até o islamismo acabaram por ser considerados de algum modo herdeiros políticos do império romano; passaram desta maneira a ser igualmente considerados como sucedâneos do quarto império. No final da Idade Média, pensadores judaicos como Abravanel mantinham-se ainda estritamente fiéis ao uso desta coordenada ${ }^{28}$.

Mais uma vez identificada como quarto império é ainda a fase em que se encontra a história do mundo que, no século XVII, o Padre António Vieira considerava ser a do seu tempo. Por muito que o «filho de homem» que, segundo Daniel $^{29}$, recebe o poder correspondente ao quinto império seja identificado com Cristo na hermenêutica teológica do cristianismo, as discussões de Vieira vão inteiramente no sentido de perceber em que moldes se fará a transição do estado de ainda quarto império para o, finalmente, quinto império ${ }^{30}$. Por essas alturas andava ele a sonhar com a ideia da transição definitiva do quarto para o quinto império e não se cansava de elaborar fórmulas precisas e modelos concretos para

${ }^{27}$ Cf. Asurmendi 2000, 507-10; Ramos 2013, 35-37.

${ }^{28}$ Cf. Netanyahu 2012, 261-66.

${ }^{29}$ Dn 7:13-14.

${ }^{30}$ É à tarefa de definir as subtilezas desta transição que Vieira consagra os longos tratados que são a História do Futuro e a Clavis Prophetarum. 
planear e preanunciar o quinto império, onde ele, com a mesma intensidade e urgência de sempre, colocava o mundo novo do futuro.

\section{Os PLURAIS E O SINGULAR}

Em suma, a categoria histórica dos impérios transformou-se numa fórmula privilegiada para processar a mitologia do tempo. Por meio deste conceito se concentram a alteridade e a tensão com que se identifica a pluralidade das nações. Nesta linguagem em que se espelham os conflitos da convivência histórica, encontra-se expressa uma versão da alteridade que intensifica as dimensões da agressividade. É a pluralidade com as suas ressonâncias negativas. Os outros, na medida em que constituem uma ameaça, são realmente assim: multitudinários e confusos, degenerados, inimigos e opressivos. Não obstante isso, existe também a pluralidade com uma ressonância positiva, podendo mesmo ser levada até ao ponto de utopia. É o convívio plural e até mesmo universal das nações retratado com as conotações de convívio que são características da utopia.

Deus faz parte de ambos os horizontes de utopia em que se exprime e se estrutura a História do mundo, com horizontes de negativo e de positivo. Ele é a utopia requerida pela necessidade de exigir a justiça e de restabelecer a ordem, seguramente mais do que as mecânicas elaboradas para explicar a origem do mundo. Deus está no processamento e no desenvolvimento da História e do mundo mais que na procedência ou origem do universo. Os mitos de origem que sublinham a intervenção divina constituem, na verdade, verdadeiros tratados sobre a essência das coisas e sobre o seu desenvolvimento histórico.

Por isso resulta biblicamente natural detectar-se alguma dialéctica entre a teologia e os impérios como fórmulas equivalentes aos vários estados de organização da História. Com efeito, os impérios são coisas próprias da História; de Deus é o Reino. Em matéria de semântica fundamental Deus e a História assentam sobre os mesmos princípios e partilham uma boa parte dos respectivos significados. É por isso que, na Bíblia bem como nas culturas pré-clássicas, se fala sempre univocamente em reino, tanto para a realeza divina utópica como para as realezas históricas. A teologia política da Mesopotâmia articulava de forma tranquila e otimista a dimensão divina e a realidade humana da reale$\mathrm{Za}^{31}$. Os dois campos semânticos, que também ali se podem claramente detectar, encerram, de qualquer modo, uma dose de dialéctica que o próprio conceito de realeza oriental e muito particularmente o da realeza bíblica partilhavam ${ }^{32}$.

O choque ocorre entre o excesso das práticas e do simbolismo imperial por parte das realezas humanas, com incidências restritivas nos direitos e na dignidade dos súbditos humanos, e o carácter utópico e inalienável em que assenta

\footnotetext{
${ }^{31}$ Cf. A famosa lista dos reis sumérios, em Kranmer 1977, 361-63.

${ }^{32}$ Cf. Ramos 2005, 14-18.
} 
a antropologia individual e social no âmbito do Reino de Deus. É o carácter absoluto da prática política como um excesso (hybris) de absolutismo, em confronto com conotações incontornáveis, absoluto e dignidade que são apanágio e direito inalienável dos humanos. Numa fronteira deste teor, os conflitos são frequentes e radicais. Tanto mais que chega a ter-se a impressão de existir uma incompatibilidade total e incontornável entre estas duas margens. Precocemente na Bíblia, esta sensibilidade chegou a levantar dúvidas de se seria correto assumir a realeza como forma de governo, apesar de ser uma fórmula consagrada pela experiência histórica dos povos orientais. As ressonâncias absolutas que o conceito de monarquia concita pareciam contradizer a ideia de que tais valores absolutos só estariam representados de forma coerente pela realeza de Deus ${ }^{33}$. No final do século XV, o judeu lisboeta Isaac Abravanel também considerava mais certa uma liderança profético-carismática para um hipotético governo do povo dos hebreus, de preferência à monarquia ${ }^{34}$.

Entretanto, continuou a verificar-se claramente uma preferência bíblicocristã pela nomenclatura de rei e de reino, aplicando a Deus e a Cristo o título de rei, mais do que o de imperador. Mesmo assim, houve épocas em que a soberania real de Cristo se acomodou igualmente bem ao conceito de império, tanto em linguagem grega (autokrátor, pantokrátor) como latina. O hino do estado-cidade do Vaticano continua a repetir o refrão Christus vincit, Christus regnat, Christus imperat. No horizonte hermenêutico do cristianismo e de acordo com a visão hermenêutica do Padre António Vieira, o quinto império identificava-se inteiramente com o plano cristológico, decorrendo uma natural cumplicidade para com o destino de Portugal e para com a função do seu rei.

\footnotetext{
${ }^{33}$ Cf. 1Sm. 8:1-18.

${ }^{34}$ Cf. Ramos 2007, 382-83.
} 


\section{BibliografiA}

Astour, M. A. 1992. “Goiim.” In The Anchor Bible Dictionary. Vol. 2, ed. D. N. Friedman, 1057. New York: Doubleday.

Asurmendi, J. M. 2000. "Daniel y la apocalítpica." In Historia, narrativa, apocalíptica, ed. A. González Lamadrid, 507-10. Estella: Editorial Verbo Divino.

Collins, John J. 2010. A imaginação apocalíptica. São Paulo: Paulus Editora.

Diez Macho, A. Apocrifos del Antiguo Testamento. Tomo 4. Madrid: Ediciones Cristiandad.

Friedman, D. N., ed. 1992. The Anchor Bible Dictionary. New York: Doubleday.

Jones, D. L. 1992. "Roman imperial cult." In The Anchor Bible Dictionary. Vol. 5, ed. D. N. Friedman, 806-9. New York: Doubleday.

Kramer, S. N. 1977. Os Sumérios. Lisboa: Livraria Bertrand.

Machinist, P. 1992. "Nimerod." In Anchor Bible Dictionary. Vol. 4, ed. D. N. Friedman, 1116-118. New York: Doubleday.

Netanyahu, B. 2012. Dom Isaac Abravanel, estadista e filósofo. Coimbra: Edições Tenacitas.

Ramos, J. A. 2013. "Oráculos bíblicos de fim projectados por sobre o fim de Roma." In A queda de Roma e o alvorecer da Europa, ed. Francisco de Oliveira, José Luís Brandão, Vasco Gil Mantas e Rosa Sanz Serrano, 3435. Coimbra: Imprensa da Universidade de Coimbra.

__ 2007. "Definir o Messias, segundo Abravanel." In Rumos e escrita da História, coord. Maria de Fátima Reis, 382-83. Lisboa: Edições Colibri. 2005. "Rei e Messias: imagens contrapostas, imagens sobrepostas." In Turres Veteras, VII. História das figuras do poder, 14-18. Torres Vedras: Câmara Municipal de Torres Vedras.

Speiser, E. A. 1964. Genesis. Garden City, NY: Anchor Bible. 
